\title{
Quality of life of male amateur athletes from Pelotas, Brazil
}

\section{Qualidade de vida de atletas amadores do sexo masculino de Pelotas/RS}

\author{
Cristiano Dall'Agnol', Rodrigo Del Ponte da Silva², Fabrício Boscolo Del Vecchio²
}

\begin{abstract}
The aims of the present study were to assess and compare the health habits and quality of life (QoL) of amateur athletes in different sports. A total of 88 male amateur athletes, engaged in team $(n=33)$, individual $(n=30)$ and combat sports $(n=25)$ aged between 18 and 35 years participated in the experiment. The subjects underwent individual anamnesis and completed the WHOQOL-bref questionnaire to measure QoL. Information on the frequency and duration of training sessions was also collected. According to the findings, team sport athletes consumed more alcoholic beverages, and those from individual sports obtained higher values in the physical (83.7 \pm 9.3 vs $76.8 \pm 9.5$ points, $\mathrm{p}=0.03)$ and environmental domains $(73.4$ \pm 11.6 vs $66.3 \pm 8.9$ points, $\mathrm{p}=0.03$ ) and overall QoL score $(81.2 \pm 6.7$ vs $75.2 \pm 7.9$ points, $\mathrm{p}=0.01)$, respectively. No correlations were found between $\mathrm{QoL}$ domains and time engaged in the sport $(\mathrm{r}=0.01 ; \mathrm{p}=0.91)$, number of weekly training sessions $(r=0.09 ; \mathrm{p}=0.39)$ and session duration $(\mathrm{r}=-0.06 ; \mathrm{p}$ $=0.59$ ). Comparison of $\mathrm{QoL}$ results with those of the general population revealed higher levels in the physical and psychological components of amateur athletes. In the present study, engaging in sports was associated with higher QoL levels in amateur athletes, particularly in the physical and psychological domains. Moreover, correlations were found between the overall score and domains of QoL.
\end{abstract}

\section{Keywords}

Quality of life; Sport; Athletic performance; Exercise; Social environment.

\section{Resumo}

Os objetivos do estudo foram avaliar e comparar hábitos de saúde e niveis de Qualidade de Vida (QV) de atletas amadores de diferentes grupos de modalidades esportivas. Participaram deste estudo 88 atletas amadores do sexo masculino, praticantes de modalidades coletivas $(n=33)$, individuais $(n=30)$ e lutas $(n=25)$ entre 18 e 35 anos. Os envolvidos preencheram anamnese individual e, para medida de QV, responderam o questionário WHOQOL-bref. Informações sobre frequência e duração de sessões de treinamento também foram coletadas. De acordo com os achados, atletas de modalidades coletivas exibiram maior consumo de bebidas alcoólicas. Quando comparados a estes, os praticantes de modalidades individuais apresentaram valores superiores nos domínios físico $(83,7 \pm$ $9,3$ vs 76,8 $\pm 9,5$ pontos, $p=0,03)$, ambiental $(73,4 \pm 11,6$ vs 66,3 $\pm 8,9$ pontos, $p=0,03)$ e no escore geral de $Q V(81,2 \pm 6,7$ vs 75,2 $\pm 7,9$ pontos, $p=0,01)$, respectivamente. Não foram encontradas correlações entre domínios da QV e tempo de prática $(p=0,91)$, frequência semanal de treino $(p=0,39)$ e duração das sessões de treino $(p=0,59)$. Ao comparar os resultados de $Q V$ com os de referência populacional, níveis mais elevados foram encontrados nos componentes físicos e psicológicos entre esportistas amadores. No presente estudo, a prática esportiva esteve associada a niveis superiores de QV de atletas amadores, particularmente nos domínios físico e psicológico. Além do mais, foram encontradas correlações entre escore geral e os domínios da QV.

\section{Palavras-chave}

Qualidade de vida; Esporte; Desempenho desportivo; Exercício fisico; Ambiente social.

\section{Introduction}

Health-related quality of life (HRQoL) scores for different populations ${ }^{1}$ have been widely discussed in academia, particularly individuals with cancer $^{2}$, cardiac disease ${ }^{3}$, stroke ${ }^{4}$, the elderly ${ }^{5}$, and those engaged in physical activity ${ }^{6,7}$. With respect to the last group, investigations have explored the relevance of physical

1 Federal University of Santa Catarina (UFSC), Master's in the Biodynamics of Human Performance Graduate Program; Department of Physical Education; Florianópolis; Santa Catarina (SC); Brazil.

2 Federal University of Pelotas (UFPEL); Department of Physical Education; Pelotas; Rio Grande do Sul, Brazil. activity (PA) in determining quality of life (QoL), demonstrating a close relationship between the two ${ }^{6-8}$. This is because regular PA can prevent chronic diseases and improve health ${ }^{7}$.

On the other hand, earlier studies showed that excessive PA may be harmful since it involves high physical stress, causes anxiety and depression, and results in different types of musculoskeletal injuries ${ }^{9-11}$. Feelings of guilt, depression, irritability, anxiety and abstinence were observed when runners were prevented from training ${ }^{10}$, with negative effects on family, so- 
cial and work relationships, and described as exercise addiction ${ }^{11}$. Athletes end up exacerbating their obsession for results, sometimes resorting to illegal substances to achieve their goals, thereby having a negative effect of QoL ${ }^{12}$.

Physical aptitude, physical activity and health are interconnected, since depending on the variables analyzed, physical exercise can have a positive effect on quality of life and, in this context, sport has been used to improve health and physical aptitude, including in non-athletes ${ }^{13}$. However, few studies have investigated the QoL of amateur athletes, in which the time and intensity of exercise are higher than in the general population ${ }^{14}$ and lower than in professional athletes ${ }^{15,16}$. In a recent study, higher QoL scores were observed in team sport compared to individual sport athletes, an effect attributed to greater athlete interaction ${ }^{14}$. On the other hand, since only a small number of subjects were compared, more studies are needed to reinforce these conclusions ${ }^{14}$.

Few studies have compared QoL between individual, team and combat sports considering important day-to-day factors, such as session frequency and duration. Rather, most of the investigations were restricted to differences between athletes of these sport modalities ${ }^{11,14}$, competitive level ${ }^{16}$ and sexes ${ }^{11,14,16}$. Thus, the aims of the study were: i) to identify possible differences in habits between amateurs engaged in individual, team and combat sports, ii) assess QoL levels and iii) relate session frequency and duration with the QoL reported.

\section{Methods}

\section{Type of study, population and characterization of variables.}

This is a cross-sectional, descriptive observational study. A total of 88 male amateur athletes from different sports aged between 18 and 35 years were assessed. The individuals underwent three or more uninterrupted weekly sessions for at least two years, and those not involved in any competition in the previous six months were excluded. All the subjects were informed regarding the aims of the study (approved by the local ethics committee, protocol no. 003/2012) and gave their informed consent.

The dependent variables were the health-related quality of life domains contained in the WHOQOL-bref questionnaire. The independent variables were sport modality (combat, individual or team), time engaged in the sport in years, session duration, age and number of sessions per week.

\section{Study design}

After permission was obtained from the coaches and previous contact with the athletes, the researchers visited the training venues, where subjects were informed about the instruments to be completed. Participants could receive the material directly from the researchers or their coach, who was previously trained (qualified) to double check the forms and answer any questions.

To analyze quality of life, individuals completed the World Health Organization Quality of Life-Bref (WHOQOL-bref) ${ }^{17,18}$. The forms were delivered and collected in two ways: at the sport venue itself or at the session after the forms were handed out. Thus, the athletes could fill out the form at home, but they were asked to do so in private to avoid external interference.

\section{Description of the WHOQOL-bref}

The WHOQOL-bref instrument, a short, validated version of the WHOQOL-100 17,18 , is composed of 26 questions in four domains, as follows: i) Physical 
health, which analyzes the variables pain and discomfort, sleep and rest, energy and fatigue, mobility, daily activities, dependence on medication and medical assistance and work capacity. ii) Psychological, involving positive feelings, thinking, learning, memory and concentration, self-esteem, body image and appearance, negative feelings, spirituality, religion and personal beliefs. iii) Social relationship domains, associated with personal relationships, social support and sexual activity and iv) Environmental, involving freedom, physical safety and security, family setting, financial resources, medical and social assistance: accessibility and quality, opportunity to acquire new information and skills, participation and opportunities for recreation and leisure, physical environment (pollution, noise, traffic, climate) and transport ${ }^{17}$.

The score of each item varies from 1 to 5 on a Likert scale and is converted into a linear scale between 0 and 100, 0 representing the worst quality of life and 100 the highest ${ }^{18,19}$. The WHOQOL-bref in Brazilian Portuguese is valid and reliable for use in the country, in addition to demonstrating good psychometric qualities $^{17}$. Information on economic and schooling level was also recorded.

\section{Data analysis}

For statistical analysis, descriptive and inferential statistics were applied after data entry and double checking the consistency of the databank, as well as testing for normality using the Shapiro-Wilk test. Absolute and relative distribution frequency (\%) mean, standard deviation (SD) and 95\% confidence interval were used to present the data. Inferential statistics used the chi-squared test for proportions and simple analysis of variance for comparisons between groups of sports. Pearson's correlation was used to assess the relationships between the variables analyzed. A 5\% level was adopted for statistical significance.

\section{Results}

The present study involved male athletes from 12 sports ( $\mathrm{n}=88 ; 27.1 \pm 2.5$ years), 25 in combat sports $(28.4 \%$ of the total, five in Muay Thai, five in karate, six in Brazilian jiu-jitsu and nine in judo), 30 in individual sports (34.1\%, 11 in tennis, seven in paddle, seven in cycling and five in triathlon) and 33 in team sports (37.5\%, seven in volleyball, seven in soccer, nine in futsal and ten in rugby). The mean age of each group was $27.1 \pm 3.8 ; 26.1 \pm 3.4$ and $27.6 \pm 3.7$ years for combat, team and individual sports, respectively, with no intergroup differences.

None of the subjects smoked, although $94.3 \%$ had smoked at least once and $5.7 \%$ two or three times. With respect to alcohol consumption, $38.6 \%$ of the athletes did not consume alcoholic beverages, $40.9 \%$ drank two or three times a week and $20.5 \%$ once a week. In this respect, those involved with team sports obtained a higher percentage $\left(81.8 \%, \chi^{2}=9.81, \mathrm{p}=0.007\right)$ when compared to individual sport (53.3\%) and combat athletes (44\%).

Only eight subjects reported using prescription drugs and $29.5 \%$ took supplements. Two individuals preferred not to reveal which or how many supplements they used, eleven used only one, eight took two types of supplement and four used three or more. Protein supplements, maltodextrin and amino acids (BCAA) were used by sixteen, nine and seven individuals, respectively. Creatine was used by five individuals and albumin, thermogenics, omega three and multivitamins by one subject each.

In relation to sport duration, those engaged in combat, individual and team sports had $8.7 \pm 6.6,8.9 \pm 5.2$ and $11.2 \pm 7.6$ years of experience, with no statistical 
differences between the groups $\left(\mathrm{F}_{2,85}=1.42 ; \mathrm{p}=0.24\right)$. In general, $75 \%$ of the athletes practiced three or four times a week and $25 \% 5$ times or more. Sessions of one hour or less involved $25 \%$ of the sample, two hours or less $72.2 \%$, and three hours or less $2.3 \%$; however, intersport differences were observed $\left(\chi^{2}=12.33, \mathrm{p}=0.01\right)$. Sessions of one hour or less were more frequent in individual compared to combat sports, but the latter group underwent more sessions of two hours or less than the former. In relation to the prevalence of lesions in the previous six months, $32 \%$ of combat, $40 \%$ of individual sport and $54.5 \%$ of team sport athletes reported some type of injury, with no differences between the sports $\left(\chi^{2}=3.13, \mathrm{p}=0.210\right)$.

In regard to quality of life, the overall WHOQOL-bref score for all those involved was $77.8 \pm 7.9$ points, with differences between sports $\left(\mathrm{F}_{2,85}=5.1 ; \mathrm{p}=0.008\right)$. The data for sport groups and WHOQOL-bref domains are presented in table 1. No correlations were observed between sport duration, number of weekly training sessions and session duration for any of the WHOQOL-bref domains or the overall quality of life score (table 2).

TABLE 1 - Descriptive measures of specific and overall quality of life scores (WHOQOL-bref) in amateur athletes from Pelotas, RS $(n=88)$.

\begin{tabular}{|c|c|c|c|c|c|}
\hline \multirow{2}{*}{ Domains } & & \multicolumn{3}{|c|}{ Sport groups } & \multirow{2}{*}{$\begin{array}{l}\text { Entire group } \\
\qquad(n=88)\end{array}$} \\
\hline & & Combat $(n=25)$ & Individual $(n=30)$ & Team $(n=33)$ & \\
\hline \multirow[t]{2}{*}{ Physical } & $x \pm s d$ & $78.1 \pm 11.5$ & $83.7 \pm 9.3^{*}$ & $76.8 \pm 9.5$ & $79.5 \pm 10.4$ \\
\hline & $95 \% \mathrm{Cl}$ & $73.4-82.9$ & $80.2-87.2$ & $73.5-80.2$ & $77.3-81.7$ \\
\hline \multirow[t]{2}{*}{ Psychological } & $x \pm s d$ & $78.5 \pm 11.6$ & $82.4 \pm 8.2$ & $77.4 \pm 9.9$ & $79.4 \pm 10.0$ \\
\hline & $95 \% \mathrm{Cl}$ & 73.7-83.3 & 79.3-85.4 & 73.9-80.9 & $77.3-81.5$ \\
\hline \multirow[t]{2}{*}{ Social } & $x \pm s d$ & $83.7 \pm 11.7$ & $85.3 \pm 10.9$ & $80.3 \pm 13.1$ & $82.9 \pm 12.0$ \\
\hline & $95 \% \mathrm{Cl}$ & $78.8-88.5$ & $81.2-89.3$ & $75.6-84.9$ & $80.4-85.5$ \\
\hline \multirow[t]{2}{*}{ Environmental } & $x \pm s d$ & $67.7 \pm 9.3$ & $73.4 \pm 11.6^{*}$ & $66.3 \pm 8.9$ & $69.1 \pm 10.4$ \\
\hline & $95 \% \mathrm{Cl}$ & 63.9-71.6 & $69.1-77.7$ & $63.1-69.4$ & $66.9-71.3$ \\
\hline \multirow[t]{2}{*}{ Overall score } & $x \pm s d$ & $77.0 \pm 8.1$ & $81.2 \pm 6.7^{* *}$ & $75.2 \pm 7.9$ & $77.7 \pm 7.9$ \\
\hline & $95 \% \mathrm{Cl}$ & $73.7-80.3$ & $78.7-83.7$ & $72.4-78.0$ & $76.1-79.4$ \\
\hline
\end{tabular}

$\mathrm{x} \pm \mathrm{sd}=$ mean \pm standard deviation; $95 \% \mathrm{Cl}=95 \%$ confidence interval * = statistically higher than team sports $(p=0.03) .{ }^{* *}=$ statistically higher than team sports $(p=0.01)$.

TABLE 2 - Correlations (with respective p-values) of WHOQOL-bref domains and overall quality of life score, with variables related to the training load of amateur athletes from Pelotas, $\mathrm{RS}(\mathrm{n}=88)$.

\begin{tabular}{lccccc}
\hline & \multicolumn{4}{c}{ Domain } & \multirow{2}{*}{ Overall score } \\
\cline { 2 - 5 } & Physical & Psychological & Social & Environmental & \\
\hline No. of sessions per week & $0.13(0.22)$ & $0.11(0.30)$ & $-0.03(0.80)$ & $0.07(0.50)$ & $0.09(0.39)$ \\
\hline Duration of the session & $-0.09(0.41)$ & $0.12(0.28)$ & $-0.13(0.22)$ & $-0.04(0.69)$ & $-0.06(0.59)$ \\
\hline Time engaged in the sport & $-0.07(0.50)$ & $0.02(0.83)$ & $-0.03(0.80)$ & $0.12(0.27)$ & $0.01(0.91)$ \\
\hline
\end{tabular}

The overall quality of life score was positively and significantly correlated with the physical $(r=0.78 ; p<0.001)$, psychological $(r=0.69 ; p<0.001)$, social $(r=0.72$; $\mathrm{p}<0.001)$ and environmental domains $(\mathrm{r}=0.74 ; \mathrm{p}<0.001)$, and the results are shown in figure 1. 

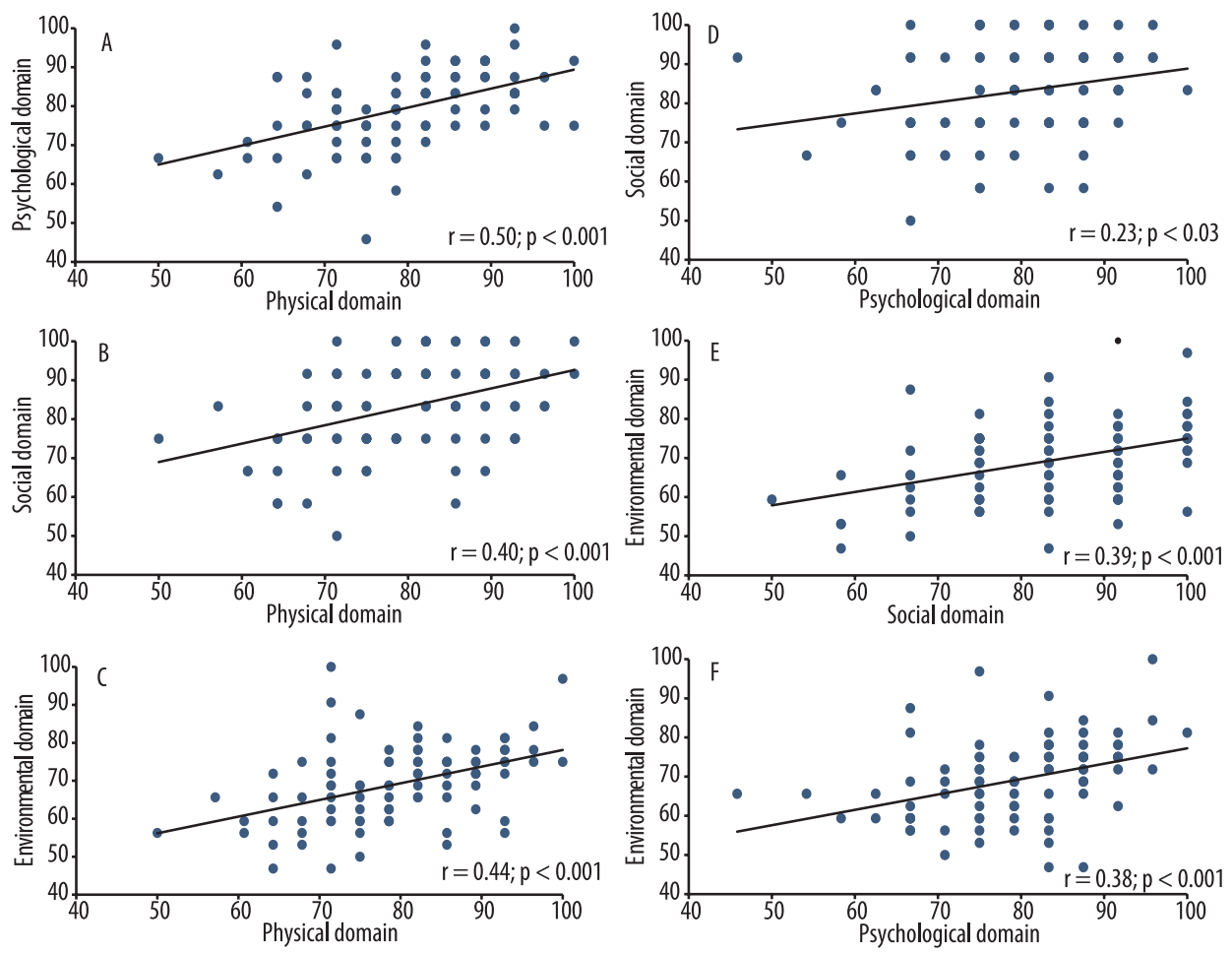

FIGURE 1 - Correlations between different quality of life domains in amateur sport athletes from Pelotas, RS $(n=88)$.

\section{Discussion}

The primary objective of this study was to measure and compare the QoL scores of Pelotas athletes, according to sport modality. Moreover, we sought to determine health habits, such as smoking, alcohol consumption and the use of ergogenics. Among the main environmental results is the greater frequency of alcohol ingestion in team sport athletes. It has been demonstrated that greater alcohol consumption is associated with social behavior in university students aged between 18 and 30 years, with males exhibiting higher weekly frequency (1.9 \pm 1.2 vs $1.2 \pm$ 1.2 days) and amount consumed compared to non-athletes ${ }^{20}$. Among the reasons that would explain the higher consumption is the pleasurable feeling after ingestion, to feel "relaxed" or "to feel better" ${ }^{20}$. The latter is related to weekly frequency of alcohol consumption in female athletes and non-athletes of both sexes, but not for male athletes ${ }^{20}$. For this population, it has been suggested that alcohol consumption is more dependent on social influence than coping ${ }^{20}$. When excessive, alcohol consumption may have a negative influence on health, frequently resulting in disease $\mathrm{e}^{21}$ and injury ${ }^{22}$. However, given the weekly training frequency of the athletes in the present study, the effects of alcohol consumption on the self-reported QoL remain uncertain. None of the athletes reported that they smoked, possibly considering the habit toxic and particularly harmful to sport performance ${ }^{23}$.

Interestingly, no differences were found in the number of weekly sessions between the sport modalities, although their duration is longer in combat athletes. Differences between these training characteristics may be due to the methodology used by the teams, time available to the athlete, or because these sports require high physical and technical demand ${ }^{24}$. The competitive level may be a factor that affects the QoL of athletes, primarily when comparing amateurs and profession$a^{16}{ }^{16}$. In the present study, the level of competition was not systematized, although nearly all the athletes have taken part in regional events. 
There was a prevalence of similar injuries over a 6-month period in the groups studied. An earlier 6-month investigation analyzed the prevalence of injuries in amateur and professional combat athletes, and found an incidence of $42.9 \%{ }^{25}$. Although physical contact is high in combat sports, a cohort study with professional boxers showed a lower incidence than in team sports such as soccer, professional rugby, hockey and basketball, suggesting that the incidence of injuries is related to the intensity at which the sport is played $^{25}$, as well as the large number of impacts in areas of the body prone to torn ligaments, overuse and sudden changes in direction ${ }^{26}$. As such, they are strongly dependent on the type of sport and the competitive stage of the athlete.

According to the WHOQOL-bref questionnaire, individual sport athletes showed higher scores in the physical domain when compared to their team sport counterparts ( $83.7 \pm 9.3$ vs $76.8 \pm 9.5$ points, $\mathrm{p}<0.05)$, which may be associated with the fact that the results depend solely on the individual ${ }^{11}$, thereby imposing greater physical demands. The physical domain involves subjective questions related to the physical perception of subjects regarding daily activities, mobility, pain, sleep, energy, medication use, and work capacity, for which participants use people close to them as a basis for comparison. Corroborating the findings of the present study, amateur individual sport athletes not dependent on physical exercise exhibit higher overall health values (SF-36 questionnaire) than their amateur team sport counterparts ${ }^{11}$.

A higher score was also found for individual sport athletes in the environmental domain $(73.4 \pm 11.6$ points) when compared to team sport athletes $(66.3 \pm 8.9$ points). It is important to remember that tennis, paddle, cycling and triathlon were considered individual sports, and that an earlier study in Pelotas involving 3,136 subjects over the age of 20 years reported that less than $1 \%$ of the population played tennis ${ }^{27}$; the other sports were not included in the study, possibly because they are associated with higher socioeconomic levels and require the use of specific venues and costly equipment. Thus, it is likely that other factors not assessed, such as economic status and schooling level, are associated with the higher environmental domain ${ }^{19}$. Correlations were found between the domains and overall score, but the WHOQOL-bref results were not correlated with time engaged in the sport or number and duration of weekly training sessions. This suggests that the improvement in QoL indices results from the playing of sports itself, with no temporal effect; rather, the simple fact of exercising seems to improve $\mathrm{QoL}^{8}$.

In relation to the social domain, it is hypothesized that higher values would be observed in team sports due to the greater interaction among athletes ${ }^{11}$, which could be transferred to daily activities; however, these differences would not be statistically significant, contrasting with the initial hypothesis. The social domain includes individual perception in terms of satisfaction with the support received from friends and families and satisfaction with sexual activity. In this case, it seems that, regardless of the way in which the sport is played, the social domain is not limited to sport interaction.

It was observed that the athletes under study obtained higher physical health values than those of the general population aged between 20 and 29 years ${ }^{19}$. These may be due to the possibility that, when planned, regular PA improves physical conditioning, enhances sleep quality and controls the use of medication, when necessary. Improved performance was also found in the psychological domain, showing that physical exercise can result in significant improvements, with a positive effect on body self-perception, concentration, and memory, as well as managing and re- 
ducing depression, factors commonly responsible for changes in this variable ${ }^{18,28}$.

The set of scores show more significant differences between individual (overall score of $81.2 \pm 6.7$ points) and team categories (overall score of $75.2 \pm 7.9$ points) ${ }^{19}$. Thus, knowing the QoL of athletes is relevant information for society, given that this information can be used to develop social policies aimed at individuals, small groups or the population in general ${ }^{29}$. However, new studies should assess whether playing sports tends to raise quality of life in athletes; ii) consider the larger number of variables, such as socioeconomic level, schooling and competitive success, since some of these variables may be directly related to QoL scores ${ }^{18,19}$. In this study, statistical calculations relating family income parameters, schooling and QoL were not conducted due to the small amount of sociodemographic information $(58 \%)$ obtained, and new studies on the subject should determine additional associations and relationships with these variables.

The results of this study revealed the differences reported by amateur athletes from different sports, whereby individual sport athletes demonstrated better perception of the physical and environmental aspects than team sport players. It is important to underscore the lack of correlation between time engaged in the sport, number and duration of training sessions and the domains. However, the athletes of this study obtained higher scores in the domains compared to general population levels, demonstrating that playing amateur sports, regardless of modality, and number and duration of the training sessions seems to raise QoL levels. Finally, correlations were found between overall score and domains, explaining the influence of each domain on the final QoL score.

\section{Author's contributions}

C. Dall'Agnol (0000-0003-0642-8174) and R. D. P. Silva (0000-0001-6211-4052) participated in collection, data tabulation, interpretation and writing. F. B. Del Vecchio (0000-0003-3771-9660) was responsible for analysis and interpretation of data, revision and approval of version to be published.

\section{References}

1. Del Vecchio FB, Corrente JE, Gonçalves A, Faria MM, Padovani CR, Vilarta R. Multivaried analysis of the interaction between quality of life and physical capacities for people occupationally intoxicated by mercury. Acta Med Port. 2007; 20(2):131-7.

2. Färkkilä N, Torvinen S, Roine RP, Sintonen H, Hänninen J, Taari K, et al. Health-related quality of life among breast, prostate, and colorectal cancer patients with end-stage disease. Qual Life Res. 2014; 23(4):1387-94.

3. Arnold SV, Masoudi FA, Rumsfeld JS, Li Y, Jones PG, Spertus JA. Derivation and Validation of a Risk Standardization Model for Benchmarking Hospital Performance for Health-Related Quality of Life Outcomes After Acute Myocardial Infarction. Circulation. 2014; 129(3): 313-20.

4. Dhamoon MS, McClure LA, White CL, Lau H, Benavente O, Elkind MS. Quality of Life after Lacunar Stroke: The Secondary Prevention of Small Subcortical Strokes Study. J Stroke Cerebrovasc Dis. 2014; 23(5):1131-7.

5. Fleck MPA, Chachamovich E, Trentini CM. Projeto WHOQOL-OLD: método e resultados de grupos focais no Brasil. Rev Saúde Pública. 2003; 37(6):793-9.

6. Gill DL, Hammond CC, Reifsteck EJ, Jehu CM, Williams RA, Adams MM, et al. Physical activity and quality of life. J Prev Med Public Health. 2013; 46 Suppl 1:S28-34.

7. Martin CK, Church TS, Thompson AM, Earnest CP, Blair SN. Exercise dose and quality of life: A randomized controlled trial. Arch Intern Med. 2009; 169(3):269-78.

8. Warburton DE, Nicol CW, Bredin SS. Health benefits of physical activity: the evidence. CMAJ. 2006; 74(6):801-9. 
9. American College of Sports Medicine. ACSM's guidelines for exercise testing and prescription. Indianapolis/ Lippincott Williams \& Wilkins; 2013. 480p.

10. Morris M, Steinberg H, Sykes EA, Salmon P. Effects of temporary withdrawal from regular running. J Psychosom Res. 1990; 34(5):493-500.

11. Modolo VB, Mello MT, Gimenez PRB, Tufik S, Antunes HKM. Dependência de exercício físico: humor, qualidade de vida em atletas amadores e profissionais. Rev Bras Med Esporte. 2009; 15(5):355-9.

12. National Institute on Drug Abuse (NIDA). Anabolic Steroids Abuse. 2006; 1-8.

13. Ribeiro YS, Mezquita LAA, Del Vecchio FB. Revisão sistemática dos efeitos do futebol recreacional em adultos não atletas. Rev Bras Ativ Fis Saúde. 2013; 18(6):655-68.

14. Interdonato GC, Greguol M. Qualidade de Vida Percebida por Indivíduos Fisicamente Ativos e Sedentários. Rev bras Ciênc e Mov. 2010; 18(1):61-7.

15. De Pauw, Roelands B, Cheung SS, De Geus B, Rietiens G, Meeusen. Guidelines to classify subject groups in sport-science research. Int J Sports Physiol Perfor. 2013; 8(2):111-22.

16. Dos Santos, ALP. Quality of Life in Professional, Semiprofessional, and Amateur Athletes: An Exploratory Analysis in Brazil. SAGE Open. 2013; 1-8.

17. Fleck MPA, Louzada S, Xavier M, Chachamovic E, Vieira G, Santos L, et al. Application of the Portuguese version of the abbreviated instrument of quality life WHOQOL-bref. Rev Saúde Pública. 2000; 34(2):178-83.

18. The Whoqol Group. Development of the World Health Organization WHOQOL-bref. Quality of life assessment. Psychol Med. 1998; 28(3):551-8.

19. Cruz LN, Polanczyk CA, Camey SA, Hoffmann JF, Fleck MP. Quality of life in Brazil: normative values for the WHOQOL-bref in a southern general population sample. Qual Life Res. 2011; 20(7):1123-9.

20. Wilson GS, Pritchard ME, Schaffer J. Athletic status and drinking behavior in college students: The influence of gender and coping styles. J Am Coll Health. 2004; 52(6):269-75.

21. Duggan AE, Duggan JM. Alcoholic liver disease: assessment and management. Aust Fam Physician. 2011; 40(8):590-3.

22. O'Brien CP, Lyons, F. Alcohol and the Athlete. Sports Med. 2000; 29(5):295-300.

23. Pesta DH, Angadi SS, Burtscher M, Robert CK. The effects of caffeine, nicotine, ethanol, and tetrahydrocannabinol on exercise performance. Nutr Metab (Lond). 2013; 10(1):1-15.

24. Del Vecchio FB, Franchini, E. Lutas, artes marciais e esportes de combate: possibilidades, experiências e abordagens no currículo em educação física. In: Souza Neto S, Hunger D. (Orgs.). Formação profissional em educação física: estudos e pesquisas. Rio Claro: Biblioética; 2006. p.99-109.

25. Zazryn T, Cameron P, McCrory P. A prospective cohort study of injury in amateur and professional boxing. Br J Sports Med. 2006; 40(8):670-4.

26. Peterson L, Junge A, Chomiak J, Graf-Baumann T, Dvorak J. Incidence of Football Injuries and Complaints in Different Age Groups and Skill-Level Groups. Am J Sports Med. 2000; 28(5):51-57.

27. Dumith SC, Domingues MR, Gigante DP. Epidemiologia das atividades físicas praticadas no tempo de lazer por adultos do Sul do Brasil. Rev Bras Epidemiol. 2009; 12(4):646-58.

28. Fox KR, Stathi A, McKenna J, Davis MG. Physical activity and mental well-being in older people participating in the Better Ageing Project. Eur J Appl Physiol. 2007; 100(5):591-602.

29. Phillips D. Quality of life: Concept, policy and practice. 1st ed. London: England; 2006.

Corresponding

Author

Cristiano Dall' Agnol

cristianodallagnol@hotmail.com
Centro de Desportos - Laboratório de Esforço Físico, Campus Universitário Trindade, Florianópolis, SC, Brazil. CEP: 88040-900, telephone: (48) 88240285; (048) 3721-9924, 